\title{
Islamic State and al-Qaeda's Foreign Fighters
}

\section{Maja Touzari Greenwood}

Center for the Resolution of International Conflicts, Copenhagen University, http://cric.ku.dk/

\begin{abstract}
This article reviews important differences in how Islamic State, Jabhat al-Nusra and Ahrar al-Sham perceive the role of the foreign fighter and outlines local dilemmas integrating foreign fighters entails for the three movements. It shows how, in addition to boosting fighting capacity, a high number of foreigners might also represent a crucial weakness.
\end{abstract}

Keywords: Foreign fighters, Syria, Iraq, Al Qaeda, Islamic State, Jabhat al Nusra, Jabhat Fath al Sham, Ahrar al Sham.

\section{Introduction}

Never before have so many foreign fighters been involved in a conflict as are currently involved in the Syrian civil war. By far the majority are fighting as part of Islamic State (IS), the al-Qaeda (AQ)-affiliated Jabhat al-Nusra and the Syrian rebel movement, Ahrar al-Sham. The United Nations (UN) has assessed that there are 15,000-20,000 foreign fighters in Iraq and Syria, but the real figure could be twice as high. ${ }^{1}$ Many are veterans of earlier conflicts such as in Afghanistan and Iraq, but others are new recruits who have been inspired by the momentum there was to replace Middle Eastern despots with Islamic rule in the wake of the Arab Spring. By far the majority of the foreign fighters come

1 However, the UN monitoring team has pointed out that all published figures are by necessity estimates, as it is impossible to access reliable and accurate data due to both practical and conceptual challenges. For example, it can be hard to know whether these figures also include people who have joined Shia militia or the Kurdish Peshmerga forces, and whether they also include the so-called 'support functions' such as the women who move to IS territories. Moreover, it is unclear whether estimates account for the numbers of foreign fighters who have been killed, returned to their home countries, or who have gone twice. 
from North Africa and neighboring countries in the Middle East, but it is thought that globally the conflict has attracted foreign fighters from up to 120 different countries (more than half of all the countries in the world), including up to 3,000-5,000 Europeans. Therefore, foreign fighters make up a considerable percentage of the fighting power of the movements, and recruitment has become yet another element in competition between IS and AQ for dominance over international Jihad. The foreign fighters are considered to have real influence on the battlefield - to such an extent that, in connection with mobilizing an international coalition to combat IS, in 2014 US Secretary of State John Kerry said that it was more important to stop the flow of foreign fighters into the organizations than to carry out air attacks on their bases. As a result, the UN Security Council adopted a resolution requiring member states to prevent their nationals from journeying out to become foreign fighters.

\section{The foreign fighter flow}

One of the reasons it has been possible to induct so many foreign fighters into IS, Jabhat al-Nusra and Ahrar al-Sham is the effective infrastructure the three movements have in Syria and their good networks in Iraq. Jabhat al-Nusra has attracted veterans from the resistance to the US invasion of Iraq led by Abu Musab al-Zarqawi from AQ, while IS can attract veterans from the same resistance forces who are loyal to Zarqawis' successors and the IS Caliph, Abu Bakr Al-Baghdadi. The roots of Ahrar al-Sham's network in Iraq go far back in time to when one of the leading figures in the movement, during another conflict, Hashim al-Sheikh was responsible for the logistics that were to lead foreign fighters through Syria and on into Iraq.

Furthermore, in another neighboring country, Turkey, the three movements' networks also play a role in securing a constant influx of foreign fighters. The border has been relatively easy to cross for most of the conflict, and therefore a large number of Turkish foreign fighters have returned to Turkey. In November 2015, about 500 Turkish nationals were imprisoned for having joined IS, and 100 for having joined Jabhat al-Nusra. Those who have returned without being arrested have good possibilities of carrying out logistical 'fixer' tasks such as establishing contact points for new foreign fighters and facilitating the route through Turkey and into Syria. Ahrar al-Sham in particular seems to have a link to Turkey, which facilitates 'safe zones' on the Turkish side of the border in which their 'fixers' can operate. At the start of the conflict, a simple and quick route into Syria was to fly directly to Turkey and then find your way to the border, where 'fixers' from diverse groups were ready to help with contacts and route planning: almost in the same way as taxi drivers in Turkish charter holiday resorts. After arriving in Syria, a British foreign fighter described the simplicity of the route on his Facebook profile: " 1 hour flight from Istanbul, 30 min drive from Hatai and bing bang boom ur in!!"” As the conflict in Syria has

2 https://twitter.com/Hunada5/status/408958518771716096. 
persisted and in some respects escalated over the Turkish border, monitoring and control have become more intensive, and more foreign fighters are now travelling overland through the Balkans and Greece. Because of the animosity between IS, Jabhat al-Nusra and Ahrar al-Sham, fighters are more dependent than before on the movements' networks during the journey and being able to cross the border between Turkey and Syria before being transported to their destinations.

Jabhat al-Nusra has been more reluctant to integrate new foreign fighters arriving at the Turkish/Syrian border who want to find a way into the movement, and it has generally demanded some form of previous contact and personal references from at least two established members before recruiting a new member. Jabhat al-Nusra has preferred to hand-pick its foreign fighters and therefore it was very dependent on its members' networks and their ability to recruit new foreign fighters. In contrast, IS seems to accept any foreign fighter, even those who do not speak Arabic, do not have previous knowledge about theology or any military training. All the recent converts, opportunists, sadists and adventurers who AQ have wanted to keep out have been welcomed with open arms by IS. Basically, all you have to do is turn up out of the blue and ask IS for a weapon.

In the following, I will review other important differences in how IS, Jabhat al-Nusra and Ahrar al-Sham perceive the role of the foreign fighter and I will describe the local dilemmas this can entail for the three movements in integrating a high number of foreign fighters. In July 2016, Jabhat al-Nusra officially left $A Q$ and re-established itself as a local Syrian rebel movement under the new name Jabhat Fath al-Sham. This chapter deals with the time up to this event and it describes some of the reasons the separation was necessary, and how Jabhat Fath al-Sham can be stronger without its association with $A Q$, while $A Q$ is possibly weaker in its competition with IS.

IS

The percentage of foreign fighters in IS has been estimated from $15 \%$ right up to $80 \%$, but the most reliable figure is in the middle at around $50 \%$. Some of them are very high ranking, such as the recently killed Chechenian, Abu Omar al-Shishani, but most are middle ranks and foot soldiers. According to some sources, combat-green foreign fighters comprise the majority of the 8,000 15,000 members of IS who are estimated to have been killed in action or by carrying out suicide attacks, and this indicates that the strategy of admitting flotsam and jetsam as foreign fighters has some logic on the battlefield. Furthermore, foreign fighters in IS have been prominent as the most brutal torturers and executioners in gruesome propaganda videos. The videos profile European foreign fighters in particular as 'prime Westerners' in order to mobilize and recruit in the West, and the Dabiq magazine and other propaganda is very much aimed at European foreign fighters in content and through its choice of the English, French and German languages. 
IS's most convincing argument for recruiting foreign fighters is the claim that it is not just an ideological, transnational Jihadi project, but also a real universal holy state, a caliphate, and thus the only legitimate affiliation for all of the world's Muslims. However, IS does not just want to unite the Ummah, ${ }^{3}$ it also wants to wage an offensive and expansive war to conquer the whole world. As the German foreign fighter 'Abu Qatada' (Christian Emde) put it: "We will conquer Europe one day. It is not a question of if we will conquer Europe, just a matter of when that will happen. But it is certain ... for us, there is no such thing as borders. There are only front lines. Our expansion will be perpetual." ${ }^{4}$ In this way, IS differs from the way in which Jihadist movements, with AQ at the head, have hitherto legitimized their campaigns of violence as a defense of Muslim areas and populations. IS is not on the defensive - it is on the attack.

IS has not just declared war against the non-Muslim part of the world, it has also declared war against Muslims it does not consider as truly faithful, such as Shiites, and Muslims it considers as fallen, which in practice can be anyone who does not recognize the legitimacy of IS as a caliphate and the authority of its leader Abu Bakr al-Baghdadi as the Caliph of all the faithful. You are with them or against them - either friend or enemy. Therefore, IS does not consider the conflict in Syria as a local and limited civil war. Like other 'provinces' such as Libya, Yemen and Afghanistan/Pakistan, Syria is considered as just one more battlefield, although an important one, in the much broader project to expand the Caliphate.

This narrative about IS as a caliphate defines how recruitment of foreign fighters is designed and it also seems to have some significance for whether it is successful. The flow of foreign fighters to IS began in earnest after 2014, when it declared a caliphate, and in the first edition of Dabiq proclaimed that immigration to its territories should therefore be considered as a religious duty. Immigrating to the IS Caliphate would not just mean redemption from sin for all sinners. Not immigrating, and by implication preferring to live in the countries of the infidels rather than the Caliphate, would be a deadly sin which, according to IS, will guarantee a place in Hell - "There is no life without Jihad and there is no Jihad without hijrah [immigration]." Those who travel from abroad to fight for IS as a movement are not temporarily 'visiting' in order later to return to their home country. Rather, they automatically become nationals of the Caliphate, with permanent compulsory military service. Leaving the Caliphate is considered desertion and is punished by execution.

The Caliphate is both symbolic and specific. It legitimizes itself through a narrative about IS as a religious entity, a spiritual state of being, a spiritual approach to politics and waging war, and simultaneously a physical state to which foreign fighters are expected to be loyal and to which they are expected to con-

Arabic theological term for the Muslim faith community.

4 Alex P. Schmid and Judith Tinnes, "Foreign (Terrorist) Fighters with IS: A European Perspective," The International Centre for Counter-Terrorism - The Hague 6, no. 8 (2015), available at https://doi.org/10.19165/2015.1.08. 
tribute. Therefore, in strict terms, there are no longer foreign fighters. Immigration to IS is considered as part of its state-building project and symbolic artefacts such as issuing passports and sealed and stamped official papers are very important. Videos have been circulated of foreign fighters who have disavowed their previous nationalities by burning their burgundy-colored passports and paying homage to the Caliphate in a sort of ceremonial oath of allegiance to IS and the rest of the world be damned. Profiles on the social media reflect an idealized life in complete observance of the edicts of Islam, where sin does not exist, community and meaning are central themes, and where foreign fighters are portrayed as heroes.

As the state-building project is at the hub, recruitment of new citizens also includes other functions than those of the solider. People who are unfit for military activities are encouraged to join other functions to maintain society, such as administrators, health personnel, builders, IT engineers, media producers, and so on. In his first speech as Caliph, Abu Bakr al-Baghdadi appealed in particular to "the scholars, and callers, especially the judges, as well as people with military, administrative, and service expertise, and medical doctors and engineers of all different specializations and fields." This opens up for a much larger group of potential immigrants such as women, children and other noncombatants. Foreign fighters are encouraged to take their partners or wives and children with them to IS territories, and single women are encouraged to immigrate alone to be married to Islamic State fighters. Women play a symbolic and practical role in establishing the idea of a society through maintaining families, and it has been estimated that they make up about $10 \%$ of the foreigners who have travelled to IS. It is therefore hard to define exactly what an IS 'foreign fighter' actually is. Perhaps he is neither 'foreign,' a 'fighter,' nor a 'he.'

However, foreign fighters are not the only citizens in the Caliphate, and the local Iraqi and Syrian IS soldiers do not always show goodwill towards their fellow citizens with foreign origins. On the day they arrive, foreign fighters are awarded privileges such as compensation for having left a more comfortable life to help the Caliphate. For example, soldiers receive more pay at USD 200 compared with the USD 130 paid to locals. Foreign fighters are also housed in enclaves in the best parts of towns like in the Syrian town of Deir Ezzour, where they were allocated houses on nearby hilltops from which they could literally look down on the local population, as a local resident commented in an article in The Wall Street Journal: "The Syrians would take the valleys and the foreigners would take the hilltops." ${ }^{5}$ In the aftermath of military defeat, there have also been complaints from local IS soldiers that foreign fighters have reproached them without justification, used them as cannon fodder, and not offered them the military support they require. Tensions between local soldiers

5 Matt Bradley, "Rift Grows in Islamic State Between Foreign, Local Fighters. Resentments over Different Treatment Erupt into Violence in Syria, Iraq," The Wall Street Journal, March 25, 2016, accessed January 17, 2017, www.wsj.com/articles/riftgrows-in-islamic-state-between-foreign-local-fighters-1458930063. 
and foreign fighters have led to deaths on several occasions, most recently in February when a Dutchman was beaten to death while in detention after having tried to escape from IS. The murder released an exchange of gunfire between foreign fighters and Iraqi IS soldiers in which at least one Iraqi was killed. IS allegedly reacted by arresting up to 70 Dutch foreign fighters and executed eight of them.

\section{Jabhat al-Nusra and Ahrar al-Sham}

Despite its more exclusive approach to recruitment, the leader of Jabhat alNusra, Abu Mohammad al-Julani, has said that foreign fighters make up $30 \%$ of the movement. Jabhat al-Nusra managed to attract a critical mass of foreign fighters in the early days of the civil war in Syria in particular, not least because of the strong AQ 'brand.' However, not necessarily all foreign fighters who have joined Jabhat al-Nusra sympathize with $\mathrm{AQ}^{\prime}$ 's international terrorism. Some of the foreign fighters have joined for solely strategic reasons, because it is the best armed and organized group and it represents the strongest front to simultaneously fight against IS and the Assad regime. Its well-trained elite troops fight for a smaller army and they are in sharp contrast to the more improvisational local groups. All Jabhat al-Nusra's foreign fighters complete a tight training program as an introduction to the movement: first, 10 days of religious schooling, then 20 days of physical military training, followed by an exam on the battlefield to test their courage and skills. "We pay a great deal of attention to the individual fighter ... we are concerned with quality, not quantity,"6 stressed Abu Adnan, a Jabhat al-Nusra militia chief in Aleppo.

Recruitment of foreign fighters for Jabhat al-Nusra has posed a dilemma for the AQ leadership. AQ's overall picture of the conflict is not limited to a specific area. On the contrary, it has a global goal to protect all Muslim areas from Western interference. Jabhat al-Nusraha, as a local branch, has had to balance AQ's general defense of Muslims with its own local goal to topple President Assad and introduce an Islamic regime in Syria. A good picture of this balancing exercise is the background of their training videos, in which pictures of President Bashar al-Assad as targets for shooting practice are flanked by the movement's banner with the text "AQ in the Levant: Jabhat al-Nusra." Among other things, this duplicity means that foreign fighters with Jabhat al-Nusra have been able to choose between returning to their home countries after having toppled President Bashar al-Assad, remaining in local branches in Syria, or remaining in AQ's international organization. Although Jabhat al-Nusra believed that it is a Muslim duty to join Jihad wherever possible, they have not considered it their job to enforce this duty (they left this to the individual's con-

6 Rania Abouzeid, “Interview with Official of Jabhat al-Nusra, Syria's Islamist Militia Group," Time Magazine, December 25, 2012, accessed January 17, 2017, http://world.time.com/2012/12/25/interview-with-a-newly-designated-syriasjabhat-al-nusra/. 
science) and therefore it has been possible to leave the movement relatively freely.

Duplicity in their focus has also meant that AQ and Jabhat al-Nusra have had to be pragmatic with regard to how they arrange their presence in Syria and their co-existence with local movements such as Ahrar al-Sham. Jabhat alNusra has therefore had a strategy drawn up that aims at building up local popularity by supplying a number of services, avoiding civilian targets and sectarian violence, and by refraining from talking about attacks in the West, but instead highlighting the Assad regime as the main enemy. The leader of $A Q$, Ayman al-Zawahiri, has learnt a lesson from when Abu Musab al-Zarqawi led foreign fighters in Iraq in 2004 and expressed his frustration that the local population would not cooperate or support them. Even at that time, Zawahiri responded with exhortations to limit violence against civilians and Shiites because this invoked resistance against $A Q$ in the local population and led to a drop in new foreign-fighter recruitment.

AQ's strategy in Syria to establish a separate and localized group, Jabhat Fath al-Sham, which prioritizes building up support among the local population and cooperating closely with other Syrian rebel movements, could be an important strategy for its more long-term goal to gain influence in Syria. In this context, it has served $A Q$ well that the international community has decided not to support the rebellion against President Bashar al-Assad, thereby leaving the field open for $A Q$ and its foreign fighters. As a leader of a local rebel group put it: "We don't want AQ here, but if nobody else helps us, we will make an alliance with them." This field of tension between forced necessity and antipathy towards giving $A Q$ 's foreign fighters control of the rebellion was also mentioned by another local militia chief, who allowed his group to come under the command of Jabhat al-Nusra: "Fighting with Jabhat al-Nusra is governed by very strict rules issued by the operations command or foreign fighters ... There is no freedom at all, but you do get everything you want." ${ }^{8}$ However, not only local rebel groups were absorbed by Jabhat al-Nusra: foreign fighter groups in Syria such as Harakat Sham al-Islam, which was originally led by ex-Guantanamo prisoner, the Tunisian Seraya al-Tuaanisa and the Chechen Jaysh ulKhilafa have also been recruited as individual militias.

One ally which is important for any rebel group, but particularly crucial for groups with many foreign fighters, is the local population. Even though Jabhat al-Nusra has had the benefit of AQ's bitter experience in Iraq, and has there-

7 Carlo Muñoz, "White House officials can't confirm defection of Syrian vice president," The Hill, August 18, 2012, accessed January 17, 2017, http://64.147.104.30/ policy/international/244239-white-house-officials-cant-confirm-defection-of-syrianvice-president.

8 Mona Mahmood and lan Black, "Free Syrian Army rebels defect to Islamist group Jabhat al-Nusra," The Guardian, May 8, 2013, accessed January 17, 2017, https://www.theguardian.com/world/2013/may/08/free-syrian-army-rebels-defectislamist-group. 
fore tried to perform civilian service functions such as establishing Sharia courts, their efforts have had a shrill paternalistic tone that has had the complete opposite effect. Social media profiles, especially of young European foreign fighters, reflect how primitive and uneducated they think the local population is, and that they consider themselves as mentors for the local population. An affiliated Jihadist said that: "When the Muhajirun came, they benefited the people in religious knowledge. Sharia academies, courts and schools were opened here, managed by Muhajirun, by brothers in the Jabhat Al Nusrah." ${ }^{\prime 9}$ However, the large percentage of foreign fighters in the Sharia court staff can just as well be a source of local dissatisfaction as of popularity, if they are interpreted as a lack of local integration in the power infrastructure.

\section{Ahrar al-Sham}

The influence of Ahrar al-Sham on the Syrian rebellion against President Bashar al-Assad is strong enough to enable it ally itself with Jabhat al-Nusra without subjecting itself to Jabhat al-Nusra's command, and this led Ayman al-Zawahiri in 2013 to ask the commander of Ahrar al-Sham in Aleppo at that time, Abu Khaled Al-Suri, to arbitrate in the conflict between Jabhat al-Nusra and IS.

Ahrar al-Sham welcomes most foreign fighters without putting great demands on them, but it reminds recruits that Ahrar al-Sham is neither a caliphate nor an emirate, but a military rebel movement. Foreign fighters are encouraged to come unmarried, therefore, but if they are already married they should bring their wives and children with enough savings to support them for two years (about USD 5,000). Furthermore, they are encouraged to stay with the movement for at least six months and to pay in advance for their stay, preferably one year at a time (about USD 50 per month), in addition to paying for their own weapon (USD 1,500).

These terms are negotiated by a network called al-Muhajirun, which claims to have been established by foreign fighters from a wide spectrum of Islamic rebel movements in Syria. The purpose of the network is to demonstrate an impression of a united Syrian rebellion rather than a rebellion characterized by internal conflict to compete with IS on recruitment of foreign fighters. The 'about us' part of al-Muhajirun's website addresses the division that arose with the conflict between IS and Jabhat al-Nusra and those who go over to the Caliphate are referred to as 'impatient,' 'blind' and 'impulsive'. At the same time, al-Muhajirun adheres to a pan-Islamic criticism of the idea of nationality by referring to the departure country of the foreign fighters as their 'so-called homelands': "After decades, when the gates of Jihad opened up [in Syria], the Muslims came swarming from all over the world ... the Muslims were stricken

9 Thomas Joscelyn, "Jihadist Front Established to Represent Foreign Fighters in Syria," Long War Journal, July 20, 2015, accessed January 17, 2017, http://www.longwarjournal.org/archives/2015/07/jihadist-front-established-torepresent-foreign-fighters-in-syria.php. 
with disappointment and frustration after witnessing the dissension and confusion that occurred amongst the mujahideen [who fight in Jihad] ... some people have left the ranks of the muhajirun [emigrants] and the mujahidun [same meaning as mujahideen]. Some went to their so-called 'homelands,' while others have been impatient and wanted to continue blindly on their way impulsively."

This coordination has been appropriate for recruiting foreign fighters for whom the narrative about a Muslim community is the fundamental raison $d^{\prime}$ être, and foreign fighters who do not want to risk focusing their energies on internal disputes in the rebellion rather than on the actual enemy, President Assad. Ahrar al-Sham is a local rebel group that sees itself as primarily engaged in a specific, geographically delimited conflict that is about toppling Bashar alAssad's regime and introducing an Islamic regime instead. However, Ahrar alSham also subscribes to the idea of a religious community stretching beyond Syrian borders. This raises the narrative about the civil war in Syria above secular politics and power struggles and makes it a question of Jihad for an Islamic regime. Although, in contrast to the Jabhat al-Nusra, Ahrar al-Sham does not claim that Jihad in Syria is the duty of every Muslim, it does claim that the Syrian conflict is a matter for every Muslim because fundamentally it is about Muslim concerns. This is an important message in recruiting foreign fighters, because it says that, although you come here as a foreign fighter, we do not consider you as 'foreign' to the conflict.

\section{Jihad's dilemmas}

The widespread contempt for local culture and traditions among European IS foreign fighters, combined with local frustration about their privileged position, shows the large number of foreign fighters as a potential Achilles heel for IS. IS risks the local population seeing it as a new occupation force, with the foreign fighters as colonizing armies. For example, IS's so-called 'morality police' patrol the streets and come down hard on everyone, especially women and the elderly, who fails to meet their strict requirements for correct appearance or behavior. One resident in Mosul described in The Wall Street Journal what has become an ordinary scene from the local market, where a foreign fighter scolded an elderly Iraqi man for, in his opinion, having a too short beard for a truly faithful Muslim. The elderly man felt that his honor was being maligned by being talked to so demeaningly by a younger person, and shocked others at the market, for whom such humiliation had become an everyday experience, by answering back with oaths and swearing. However, what is more surprising and interesting is that six local IS soldiers who also observed the slanging match, took the side of the old man, clapped the foreign fighter in handcuffs, and drove him away in a car. This reflects an important dilemma for IS: It recruits foreign fighters on the basis of the higher position and relatively free rein with regard to violence they will have in the Caliphate. At the same time IS has to find a cultural sensitivity if it is not to be the object of hate from the local pop- 
ulation, and it has to quell the internal dispute between its foreign fighters and the local soldiers who also pose a threat to the movement's cohesiveness. Perhaps the 59 countries in the coalition against IS can make do with just arming themselves with patience while the internal disputes tear the movement apart and dissolve any local support there may be at the moment.

Despite the fact that Jabhat al-Nusra has in contrast had the benefit of AQ's harsh lesson on the importance of building alliances with the local rebel groups and support from the local population, focus on a moderate and pragmatic line, however, has also caused internal conflicts, which ultimately have probably contributed to the dissolution of the affiliation with $A Q$. Powerful conservative forces have not wanted to compromise on their ideology and have moved towards the much more compromiseless profile of IS. AQ's strong 'brand' has been crucial in attracting foreign fighters, especially in competition with IS, but it has been difficult for $A Q$ to profile the fighting in Syria as having something bigger and more holy at stake than nationalism. Pan-Islamic Jihadists would never sacrifice their lives in a struggle about nothing more than secular state power. In an attempt to resolve this dilemma and compete with the attraction of the Caliphate proclaimed by IS, Abu Mohammad al-Julani has therefore declared on several occasions that Jabhat al-Nusra will work towards establishing an Islamic Emirate in Syria. Like the Caliphate, foreign fighters will also be able to immigrate more formally ${ }^{10}$ to an emirate, although an emirate will be very different from a caliphate as it will only apply to the territory it controls, i.e. it does not have the universal nature of a caliphate. On the other hand, the idea of an emirate created a new dilemma for Jabhat al-Nusra, as the local rebel movements were afraid of losing control over their lands and suddenly finding themselves living in an AQ state, just as isolated and condemned as Taliban's Afghanistan or the Hamas government in Gaza. Yet again, for Jabhat al-Nusra it was a case of 'damned if you do, damned if you don't.' The only solution to the dilemma has been to take the final step to remove $A Q$ from the equation and to re-establish itself as a Syrian rebel movement that can become the organizational base of the Emirate.

At the same time, the establishment of Jabhat Fath al-Sham also makes the strategically crucial alliance with Ahrar al-Sham significantly less contentious. Ahrar al-Sham's dilemma has been the exact opposite of Jabhat al-Nusra's: Strategically it has been wise for Ahrar al-Sham to downplay its connection with $A Q$ towards the international community in order to keep the door open for donations and support, and although the group uses the term Jihad and is planning to introduce Islamic rule at the more conservative end of the scale, the 'West' is not considered an enemy. Ahrar al-Sham has interests in representing a semi-legitimate face of the Islamist element of the rebellion against Bashar al-Assad which it shares with the international community. Most recently in 2016, the UN decided that Ahrar al-Sham should not be included on its

10 What has become known by its theological term as hijra. 
list of designated terrorist groups in order to keep open the possibility of bringing it into play as a political negotiation partner. However, Ahrar al-Sham has had to maintain this interest at the same time as having a military strategic alliance with Jabhat al-Nusra, whose parent organization, AQ, shared a place with IS as the West's enemy number one. Special forces from Jabhat al-Nusra remain intact with the establishment of Jabhat Fath al-Sham and they are an important supplement to the foot soldiers of Ahrar al-Sham and it makes great sense for Ahrar al-Sham to highlight this alliance in order to recruit potential foreign fighters. On the other hand, the establishment of Jabhat Fath al-Sham reinforces the duplicity that characterizes Ahrar al-Sham, and foreign fighters will also demand a reply from Jabhat Fath al-Sham to the decisive question they have hitherto posed to Ahrar al-Sham: is their fight in Syria a fight for freedom or a pan-Islamist Jihad?

\section{About the author}

Maja Touzari Greenwood (MA) is a Doctoral Candidate at the Danish Institute for International Studies and the Center for the Resolution of International Conflicts, Copenhagen University. 